\title{
MiT Family Translocation-Associated Renal Cell Carcinoma
}

National Cancer Institute

\section{Source}

National Cancer Institute. MiT Family Translocation-Associated Renal Cell Carcinoma.

NCI Thesaurus. Code C154494.

A renal cell carcinoma (RCC) usually seen in children or young adults. It is characterized by papillary, alveolar and nested growth patterns with clear and eosinophilic cells. The carcinomas range from microscopic lesions to clinically symptomatic tumors. It is associated with translocations/gene fusions involving members of the MiT family of transcription factors, including TFE3 and TFEB. There are two subtypes; RCCS associated with Xp11 translocations and TFE3 gene fusions and RCCs with $\mathrm{t}(6: 11)$ translocations resulting in MALAT 1-TFEB gene fusions. 